\title{
We Will Not Be Silent: Amplifying Marginalized Voices in LIS Education and Research
}

Amelia N. Gibson and Sandra Hughes-Hassell

\begin{abstract}
This article focuses on the role of LIS faculty and researchers in the aftermath of the 2016 presidential election. Key points include our responsibility to educate ourselves about marginalization and silencing; to help our students build theoretical, practical, and ethical foundations for engaging with communities in ways that prioritize their needs and uphold the values of the profession; to amplify the voices of people systematically targeted by the presidential administration's policies and actions; and to engage in public discourse about the implications of current administrative policies as related to the core values of LIS, such as the right to privacy, access, freedom of speech, and intellectual freedom. The article draws parallels between social oppression, as demonstrated in campaign rhetoric and presidential policy, and institutional oppression within library spaces.
\end{abstract}

Published version can be found in The Library Quarterly:

Gibson, A. N., \& Hughes-Hassell, S. (2017). We Will Not Be Silent: Amplifying Marginalized Voices in LIS Education and Research. The Library Quarterly, 87(4), 317-329.

https://doi.org/10.1086/693488 
I saw a girl get kicked out of the library last week.

She was maybe 16, with long braids and a shy but easy smile. She had come into the library with a small group of friends and did not look fully comfortable in the space. They sat at a table together, in the way that teenage girls often do-three or four at a time (safety in numbers) and with a touch of attitude. She was new to this library, just as I was, glancing up and around at the glass walls and open stacks, respectfully quiet, except for low whispers to her friends. I watched her from my study room. My research assistant walked around the library, talking to teen girls about our research study. She chatted with the girl and her friends and walked away. A few minutes later, the girl popped her head into the room where I sat and, shyly, asked a question. I smiled, answered, and watched as she went back to her friends. She stood. They sat. She whispered, they whispered, and they looked back in my direction. I smiled. Then the guards showed up. Two guards, from opposite ends of the library. One stepped uncomfortably close to the girl, in a way I have seen before. It is the way some adults stand when asserting dominance over black teens: with a banal disregard for vulnerability and no sense of impropriety at invading the personal physical space of a teenage girl. When the guard spoke, the girl flinched and backed up slightly, and her face flashed with anger and indignation. She said something back, and the second guard pointed to the exit. The girls left. The guards wandered back to their stations.

I was later assured that the girl must have been making noise or wandering (neither of which was allowed in the library). Teens who used the library space, I was told, had to be sitting and engaged in active study or they would be asked to leave. They were not permitted to wander, and they had to remain quiet.

\section{A Brutally Crafted Facade}

Exceptionalist lore (whether tales of American libraries as community anchors and bastions of intellectual freedom or of America as a land of equal opportunity) has always relied on the invisibility of the oppressed and the silencing of voices that challenge a country's (or a field's) view of itself as noble and just (Sue 2004; Franklin 2014). In the United States, structural exclusion of minorities from public institutions has long been regarded as an acceptable tradeoff for a veneer of social order and prosperity (Bonilla-Silva 2010). In keeping with this tradition, the 2016 election season brought campaign promises of increased law and order in the form of codified harassment and oppression for many already marginalized groups of people in the United States. Preelection calls for a national stop-and-frisk program to reduce "inner city" crime among "the African-Americans" (Cornwell 2017), promises to appoint a Supreme Court justice to overturn Roe v. Wade (Mangan 2016; Nelson 2016), the promise of an extended wall on the American-Mexican border and reduced civil liberties for undocumented immigrants (Ellis 2016), open insult of people with disabilities (Harnish 2017), and promises of rollbacks on recently enacted protections for LGBTQ1 individuals (Battle and Wheeler 2017) all portended reduced civil freedoms for people of color, women, immigrants, and people with disabilities in the name of law and order, security, and nationalism. In the first months of the new administration, the administration has made clear its dedication to achieving order and prosperity through policies that cause further harm to groups that are already marginalized (Hulse 2017; Jost and Lazarus 2017; Masri and Senussi 2017; McCarthy 2017).

\section{Hypervisibility, Invisibility, and Disproportionate Scrutiny}

The increased public focus (by the president and his administration) on potential criminality 
among African Americans, immigrants, and Muslim Americans invokes a damaging paradox often experienced by marginalized people in the United States: the combination of hypervisibility and invisibility (McDonald and Wingfield 2008; Mowatt, French, and Malebranche 2013). "Hypervisibility" (or extreme visibility) describes increased scrutiny or expectations applied to a group because of difference. It is characterized by extra attention to a particular group based on differences such as race, culture, or gender, and it can subject members of the group to arbitrary enforcement, higher expectations, stereotyping, and other additional burdens. "Invisibility" refers to the suppression (by self or others) or lack of recognition of personal or cultural expression, speech (in all of its forms), or influence. In the prologue to his novel Invisible Man, Ellison (1952) writes, "I am a man of substance, of flesh and bone, fiber and liquids-and I might even be said to possess a mind. I am invisible, understand, simply because people refuse to see me. ... When they approach me they see only my surroundings, themselves, or figments of their imagination-indeed, everything and anything except me" (3).

This phenomenon can be seen in the continuous use of "Chicago" as a coded reference to violence in black communities despite higher levels of crime in other American cities, emphasis on "radical Islamic terror" (and a simultaneous de-emphasis of domestic terrorism), and increased emphasis on violent crimes committed by immigrants, despite lack of evidence of higher levels of violent crime by this group (Green 2016). Nicole Cooke (2014) describes the paradox as it plays out among faculty: "It is easy to ignore a minority faculty member in a meeting, but when a 'diverse perspective' or 'diversity representative' are needed, said faculty member is put on the spot and asked to represent an entire race, ethnic or minority group (i.e., the disabled, LGBTQ, etc.)" (43). A similar dynamic is often experienced by youth of color in library spaces (as we see in the introductory narrative). Institutional policies often normalize middle class, heterosexual, able-bodied whiteness (Furner 2007) through formal codes of conduct and informal policies.

Many of these policies simultaneously silence youth of color (literally and figuratively) and make them hyper-visible and subject to increased scrutiny and enforcement.

\section{Silence and Exclusion}

The embrace of exclusion and silencing extends beyond rhetoric. The right to vote is one of America's most prized civil rights, and one of the most powerful forms of public speech (Pettitand Sykes 2015; Derfner and Hebert 2016) in the United States. During this election, which was the first since the Supreme Court effectively struck down section 5 of the Voting Rights Act of 1965 with the Shelby County v. Holder decision, ${ }^{1}$ several states (including North Carolina) changed their election rules in ways that restricted voting by people of color, who largely voted for Democratic candidates. In North Carolina, state lawmakers were rebuffed by the courts for attempting to enact policies that would "target African Americans with almost surgical precision," ${ }^{2}$ even as the GOP campaign celebrated declines in African American participation at the polls (Mueller 2016). In a postelection speech, the president-elect thanked African Americans-not for voting for him, but for not turning out for the election at all (Rupar 2016). In a country the vote is often framed as the voice of the people, in the aftermath of intentional voter suppression, the president-elect of the United States thanked a race of people for its silence. Of course, none of this rhetoric or action was new. The exclusion and silencing of

\footnotetext{
${ }^{1}$ Shelby County, Alabama v. Holder, 570 U.S. 2 (2013).

2 North Carolina State Conference of the NAACP v. McCrory, 831 F.3d 204 (4th Cir. 2016).
} 
people of color, LGBTQ1individuals, women, people with disabilities, immigrants, and others is as old as the country (Widdersheim and McCleary 2016; Hudson 2017; Kteily and Bruneau 2017) and has taken many forms. Open suppression of participation in (or complete exclusion from) the electoral process (Combs 2016; Nagel 2016), exclusion through selectively enforced standards (Osborne 2004), and misinformation campaigns (Stringer 2008) have historically been used to explicitly exclude marginalized groups from social and political institutions and spaces. With time, and with reduced social acceptance of open prejudice, more sophisticated methods developed.

As Justice Ginsburg wrote, "Second-generation barriers come in various forms."3 In "postracial" America, the silencing of marginalized people is also achieved through the adoption of "colorblind" policies that disproportionately affect people of color, the de-prioritization of issues related to marginalized people in favor of promoting more "neutral" values, and control of narratives (current, historical, and archival), classification, definitions, and language (Honma 2005; Aguilera 2016). Although they are manifested in different ways, and sometimes unintentional, these barriers persist in many American institutions.

\section{The Complicity of Libraries}

This brings us back to the library (and our opening narrative). Patricia McDonough (1997) wrote that "organizational cultures are linked to wider socioeconomic status cultures" (107). The criminalization of black childhood in American learning spaces has been well documented and theorized in the sociological and educational literature (Monroe 2005; Morris 2016; Wun 2016). Black children are punished and suspended at disproportionately high rates across the United States and as early as prekindergarten (Smith and Harper 2015). Monique Morris (2016) noted a trend of pushing black teen girls out of school settings for age-appropriate behaviors such as "standing up for themselves, asking questions, wearing natural hair, wearing revealing clothing, and in some cases, engaging in unruly (although not criminal or delinquent) acts" (55).

Black girls bear an intersectional burden that stems from the stereotypes held by adults in their learning spaces; when the troublesome-teen stereotype is compounded by the image of the Sapphire (i.e., the angry black woman), conflict often ensues. As Morris noted, "This misunderstanding sometimes manifests when girls speak their opinion . . . or if they stand up for themselves when they feel that they have been disrespected by peers or by adults" (59). When this conflict occurs with a librarian, potentially valuable relationships are lost. When this conflict is with a school resource officer, a library guard (armed or unarmed), or a police officer potentially devastating effects can follow.

Avoiding these conflicts can become a matter of self-preservation. Most girls have no choice but to go to school, but many can (and do) avoid the library (Agosto and Hughes-Hassell 2010; Kumasi 2012). To preserve their safety, they render themselves literally and figuratively silent, invisible in or absent from the library space. Despite extensive research on the information and developmental needs of teens (Agosto and Hughes-Hassell 2005; Meyers, Fisher, and Marcoux 2007), and despite the recent national conversation around the dangers that overpolicing present for people of color in general and black teens in particular (Moore et al. 2016), many local libraries still employ inappropriate (and arbitrary) codes of conduct that serve to silence

\footnotetext{
3 J. Ginsburg dissent to Holder, 570 U.S. 2 (2013)
} 
and exclude vulnerable groups in the interest of maintaining law and order. As a field, we know better, but these practices persist.

The tactics used to control library spaces are not very different from those used to control the vote. These include open displays of physical force for suppression and exclusion of dissidents from the space, misinformation about rules for participation (or giving library and security staff large amounts of discretion in determining eligibility for use of library facilities), and exclusion through selectively enforced behavioral standards. The perpetuation of these types of policies and practices is achieved through what we have called "second-generation policies."

These include the deprioritizing of issues related to exclusion and marginalization among library administration in the LIS classroom, in grant funding, and in policy making in favor of more "neutral" values. They also include de-legitimization of narratives of exclusion and marginalization in American libraries and the crafting of categories, definitions, and other language to invalidate the experiences of the marginalized. Social responsibility, access, democracy, diversity, nondiscrimination, and equal justice are among the core values of the American Library Association (ALA 2004) and the Association for Computing Machinery (1992). This suggests that LIS faculty have a responsibility to work against systemic oppression, which results in silencing and disenfranchisement of community members. This responsibility has become more difficult to ignore and more difficult to fulfill in the wake of the 2016 election. The defense of values that were largely uncontroversial within the field (e.g., free and equal access to information, diversity, libraries as integral to democracy, and social responsibility) has become controversial and partisan as university faculty, libraries, and organizations debate how to weather the new administration (e.g., the recent \#NotMyALA controversy). ${ }^{4}$

Merely weathering the administration is not an acceptable goal for LIS faculty or libraries. Instead, we believe that as a profession, we must embrace our social justice roots and act. The survival of libraries as institutions means nothing if the people we purport to serve, whose interests we say we center in our work, are pushed further to the margins of society, intentionally silenced, and increasingly denied full participation in a democratic society. We discuss four roles that LIS faculty must assume now as we stand in solidarity with people of color, LGBTQ1individuals, women, people with disabilities, immigrants, and others whose very existence is under attack.

\section{Four Roles for LIS Faculty in the Aftermath of the Election}

\section{Know the Issues, the History of the Field, and the Community}

If faculty want to make positive impacts on this postelection environment, they first need to be willing to confront racism, sexism, homophobia, ableism, and other forms of discrimination (structural and individual) in their research, in the classroom, among the faculty, with community partners, and in professional organizations. Unwillingness to address these issues is not neutrality. It is complicity and acquiescence to the replication of broader systems of oppression within libraries and LIS programs. This complicity results in silencing that, at worst, completely excludes marginalized groups and, at best, renders them invisible.

\footnotetext{
4 "\#NotMyALA Writings by Library Community," \#NotMyALA (blog), December 17, 2016, https://notmyala.blogspot.com/2016/12/notmyala-writings-by-ala-members-and.html
} 
We will not be silent (Gibson \& Hughes-Hassell, 2017)

Deconstructing oppressive institutions is not just a matter of goodwill or good intention. As faculty, we have a responsibility to familiarize ourselves with research relevant to our field and to ground our pedagogy and inquiry in existing theoretical and ethical frameworks. This includes the responsibility to make ourselves aware of history, current issues, and ongoing debates; familiarizing ourselves with the stakeholders and affected communities; and learning from those who have done the work before us. Working toward equity is no exception.

\section{Build Students' Theoretical, Practical, and Ethical Foundations}

A critical element of working toward equity involves engaging students in explicit discussions about power, social structures, and the role of information professionals in the creation of systems and services that shape others' ability to access information about their lives and the world. Ignoring concepts such as race, intersectionality, and power represents tacit promotion of a colorblind epistemology and pedagogy that promotes whiteness as normative, dismisses discussion of marginalized experiences as disruption to the norm, and "unwittingly perpetuate[s] the false narrative that their coursework is 'neutral' and 'unbiased' rather than ideologically and politically informed and racialized" (Cooke, Sweeney, and Umoja 2016, 120). Shying away from discussions about institutionalized racism, sexism, ableism, classism, and other forms of structural oppression might help faculty avoid difficult conversations or might alleviate their fear of being perceived as partisan or politically biased by students or administrators, but doing so leaves students unprepared for the task of creating equitable systems once they join the workforce.

To prepare LIS students and graduates to confront oppression, to understand "how power and privilege shape LIS institutions and professional practice" (Cooke et al. 2016, 107), to embrace social justice as an LIS value (Pawley 2006; Schroeder and Hollister 2014; Cooke et al. 2016), and to understand the ethical implications of their decisions and practices requires that faculty intentionally help students develop the theoretical, practical, and ethical foundations they will need to engage with marginalized and silenced communities in ways that prioritize community needs and uphold the values of the profession. It requires faculty to prepare students to employ critical theories and methods as they incorporate the perspectives and values of marginalized and silenced communities, examine how libraries participate in systems of oppression, explore ways for librarians to dismantle these systems, and guide their efforts to work with "patrons and communities to co-investigate the political, social, and economic dimensions of information, including its creation, access, and use" (Tewell 2016, par. 1). It also requires faculty to introduce students to ethical and moral frameworks and to encourage students to engage in habits of ethical reasoning, and to routinely examine their impact on the lives of marginalized communities.

\section{Amplify Voices of the Marginalized}

Working toward equity also means that LIS faculty must incorporate and amplify the voices of marginalized communities in their teaching and research, among faculty, with community partners, and in professional organizations to counteract and challenge the stories of the dominant group (Delgado 1989), to assert and acknowledge the importance of the personal and community experiences of people of color and other marginalized communities (Dixson and Rousseau 2006), and to promote the scholarship of faculty of color, whose work is often relegated to the margins (Villalpando and Delgado Bernal 2002). The centrality of the experiential knowledge of people of color and other marginalized communities is a central 
concept in critical race theory (Solórzano and Yosso 2001; Yosso 2006). As Dolores Delgado Bernal (2002) explains, the lived experiences of people of color and other marginalized communities are legitimate, appropriate, and critical to understanding, analyzing, and challenging oppressive structures, practices, and discourses. Critical race scholars and educators intentionally center the voices of members of marginalized communities to refute the dominant ideology and to support members as they "find their voices" (Yosso 2006, 171). Tara J. Yosso (2006) explains:

"Those injured by racism and other forms of oppression discover that they are not alone; moreover, they are part of a legacy of resistance to racism and the layers of racialized oppression. [Thus] they become empowered participants, hearing their own stories and the stories of others, listening to how the arguments against them are framed, and learning to make the arguments to defend themselves" (173).

\section{Engage in Public Discourse}

If LIS faculty are serious about challenging oppressive systems, we also have a responsibility to engage in public discourse about the implications of the current administration's policies as they relate to the core values of the field, such as access, democracy, public good, intellectual freedom, diversity, and social responsibility (ALA 2004). Our responses must be not only public but also immediate and substantive. We must not be afraid to hold the administration accountable for its actions or to hold the field of LIS, libraries, and our colleagues accountable for embodying (or not embodying) our core values. How do we do this? What might this look like? We share three examples.

On the Thursday after the election, in response to reports of increased bullying of marginalized students in our nation's schools (Southern Poverty Law Center 2016), we worked with students and alumni of the University of North Carolina at Chapel Hill School of Information and Library Science to develop a publicly available Google document titled, "The Role of Teen Librarians and Staff in the Current Social Climate." Our goal was to provide public and school librarians who work with teens with concrete strategies and resources to use in support of marginalized students, including immigrants, Muslims, African Americans and LGBTQ1 students, who were experiencing heightened anxiety as a result of emboldened and politicized bullying (Southern Poverty Law Center 2016).

On the day following the election, R. David Lankes (2016), director of the School of Information and Library Science at the University of South Carolina, authored a blog post titled, "The Knowledge School and an Election Mandate." In his message, Lankes articulated the role of LIS schools postelection. He wrote, "Our role is not simply to document the campaign. Our role is not simply to analyze the data generated by the candidates. Our role is to act" (par. 4). Lankes continues to speak out publically about the role of LIS faculty in response to new administrative policies and actions. On February 24, 2017, for example, he called on scholars and academics in the information domains "to work with communities around the country and around the world to actively build knowledge and a common framework for evaluating the work of politicians, scientists, activists, and the citizenry" (par. 3). Lankes' continued public engagement demonstrate the role LIS faculty must take as public intellectuals who are unafraid to monitor and respond to federal and state policies that conflict with the values of the profession and intentionally or unintentionally limit the civil liberties of members of marginalized communities.

On November 18, 2016, when ALA's Washington office issued a press release titled, "Libraries 
Bolster Opportunity: New Briefs Show How Libraries Support Policy Priorities of New Administration," the reaction from the ALA membership, which interpreted this message as capitulating to and normalizing the incoming administration, was swift and loud. The press release was immediately withdrawn, and the ALA executive committee moved quickly to solicit ALA members' thoughts, ideas, and feedback to help guide them in their future discussions and plans for working with the administration. They also reaffirmed their commitment to ALA's core values, apologized to members, and acknowledged the need to earn back their trust (J. Todaro and ALA Executive Committee, personal communication, November 21, 2016).

Many members of ALA are faculty at LIS schools or academic librarians with faculty status. By joining their voices with those of ALA members who work in school and public libraries and other information settings, they demonstrated their commitment to hold the field accountable for embodying our core values and for publicly, and vigorously, opposing administrative actions that further marginalize, exclude, and silence segments of American society.

These three examples demonstrate deliberate choices by LIS faculty to act in the wake of the election-to embrace the field's commitment to "combat prejudice, stereotyping, and discrimination against individuals and groups in the library profession and in library user populations on the basis of race, age, sex, sexual orientation, gender identity, gender expression, creed, color, religious background, national origin, language of origin or disability" (ALA 2005,1). Through actions such as these, LIS faculty publically embody the core values of the profession. This is a powerful message to send to our students and to the communities we serve.

\section{Concluding Thoughts}

The open marginalization, social exclusion, and silencing that have pervaded public and political speech since the 2016 election season are not new phenomena. Marginalized people have experienced varying degrees of oppression throughout the history of the country. What is new is that the impacts of recent presidential rhetoric (and action) have implications beyond traditionally marginalized populations. For LIS, there is a perception of new threats to traditionally neutral values, such as freedom of speech, intellectual freedom, and privacy. In reality, these rights have always been contested for marginalized people-even (and sometimes especially) in libraries. Inasmuch as the election highlighted a convergence of interests (Bell 1980) between marginalized groups and the field of LIS, it also mirrors a certain level of hypocrisy present within the field, which has used (and which continues to use) many of the same tactics for social control of marginalized people (albeit in more sophisticated, purportedly socially acceptable ways). Despite periodic forays into diversity, libraries and library schools have long been complicit in exclusion, even as they promised that they were for everyone.

As a field, we are presented with a dilemma. Should we keep our heads down quietly and hope that no one notices us and our values? Or should we do the difficult work of continuous learning and introspection, continued development of our pedagogy, and open public discourse about our values? Should we choose not to speak for fear that our expertise might touch on current political concerns (i.e., real life)? Or should we be proactive in our personal learning, research agendas, pedagogy, and community engagement? We embrace the last. As faculty, we can use our privilege to challenge social and institutional systems that silence and marginalize. When we have the courage to break our own silence, we can make room for others to speak. 


\section{References}

Agosto, Denise E., and Sandra Hughes-Hassell. 2005. "People, Places, and Questions: An Investigation of the Everyday Life Information-Seeking Behaviors of Urban Young Adults." Library and Information Science Research 27 (2): 141-63.

Agosto, Denise E., and Sandra Hughes-Hassell. 2010. Urban Teens in the Library: Research and Practice. Chicago: American Library Association.

Aguilera, Jasmine. 2016. "Lawmakers Object to Library of Congress Replacing the Term 'Illegal Alien."' Seattle Times, July 25. http://www.seattletimes.com/nation-world/lawmakersobject-to-the-library-of-congress-replacing-the-term-illegal-alien/.

ALA (American Library Association). 2004. "Core Values of Librarianship." http://www.ala.org/advocacy/intfreedom/statementspols/corevalues.

ALA (American Library Association). 2005. "Diversity Statement." http://www.ala.org/aboutala/sites/ala.org.aboutala/files/content/governance/policymanual /Links/Policy\%20Manual\%2060.3.pdf.

Association for Computing Machinery. 1992. "ACM Code of Ethics and Professional Conduct." https://www.acm.org/about-acm/acm-code-of-ethics-and-professional-conduct.

Battle, Sandra, and T. E. Wheeler II. 2017. "Dear Colleague Letter." U.S. Department of Justice Civil Rights Division and U.S. Department of Education Office for Civil Rights, February 22. http://i2.cdn.turner.com/cnn/2017/images/02/23/1atransletterpdf022317.pdf.

Bell, Derrick A., Jr. 1980. "Brown vs. Board of Education and the Interest Convergence Dilemma." Harvard Law Review 93 (3): 518-33.

Bonilla-Silva, Eduardo. 2010. Racism without Racists: Color-Blind Racism and the Persistence of Racial Inequality in the United States. Lanham, MD: Rowman \& Littlefield.

Combs, Barbara Harris. 2016. "Black (and Brown) Bodies Out of Place: Towards a Theoretical Understanding of Systematic Voter Suppression in the United States." Critical Sociology 42 (4-5): 535-49.

Cooke, Nicole A. 2014. "Pushing Back from the Table: Fighting to Maintain My Voice as a Pretenure Minority Female in the White Academy." Polymath 4 (2): 39-49.

Cooke, Nicole A., Miriam Sweeney, and Safiya Umoja. 2016. "Social Justice as Topic and Tool: An Attempt to Transform a LIS Curriculum and Culture." Library Quarterly 86 (1): 10724.

Cornwell, Rupert. 2017. "Barack Obama's 2008 Speech on Race in the United States." Independent, January 14. http://www.independent.co.uk/news/world/americas/barackobama-2008-race-speech-in-full-rev-jeremiah-wright-us-president-orator-philadelphiaa7520331.html.

Delgado, Richard. 1989. "Storytelling for Oppositionists and Others: A Plea for Narrative." Michigan Law Review 87 (8): 2411-41. 
Delgado Bernal, Dolores. 2002. "Critical Race Theory, LatCrit Theory, and Critical RacedGendered Epistemologies: Recognizing Students of Color as Holders and Creators of Knowledge." Qualitative Inquiry 8 (1):105-26.

Derfner, Armand, and J. Gerald Hebert. 2016. "Voting Is Speech." Yale Law and Policy Review 34 (2): 471.

Dixson, Adrienne D., and Ceclia K. Rousseau. 2006. "And We Are Still Not Saved: Critical Race Theory in Education Ten Years Later." In Critical Race Theory in Education: All God's Children Got a Song, edited by Adrienne D. Dixson and Cecilia K. Rousseau. New York: Taylor \& Francis.

Ellis, Kate. 2016. Disability Media Work: Opportunities and Obstacles. New York: Palgrave Macmillan.

Ellison, Ralph. 1952. Invisible Man. New York: Random House.

Franklin, Sekou M. 2014. After the Rebellion: Black Youth, Social Movement Activism, and the Post-Civil Rights Generation. New York: New York University Press.

Furner, Jonathan. 2007. "Dewey Deracialized: A Critical Race-Theoretic Perspective." Knowledge Organization 34 (3): 144-68.

Green, David. 2016. "The Trump Hypothesis: Testing Immigrant Populations as a Determinant of Violent and Drug-Related Crime in the United States." Social Science Quarterly 97 (3): 506-24.

Harnish, Andrew. 2017. "Ableism and the Trump Phenomenon." Disability and Society 32 (3): 423-28.

Honma, Todd. 2005. "Trippin' over the Color Line: The Invisibility of Race in Library and Information Studies."

InterActions: UCLA Journal of Education and Information Studies 1 (2): article 2.

Hudson, David J. 2017. "On 'Diversity' as Anti-Racism in Library and Information Studies: A Critique." Journal of Critical Library and Information Studies (1): 1-36.

Hulse, Carl. 2017. "Unity Was Emerging on Sentencing. Then Came Jeff Sessions." New York Times, May 14. https://www.nytimes.com/2017/05/14/us/politics/jeff-sessions-criminalsentencing.html?_rp0.

Jost, Timothy S., and Simon Lazarus. 2017. "Trump's Executive Order on Health Care-Can It Undermine the ACA if Congress Fails to Act?" New England Journal of Medicine 376:1201-3.

http://www.nejm.org/doi/full/10.1056/NEJMp1701340?afpR\&rsspcurrentlssue\#tparticle.

Kteily, Nour, and Emile Bruneau. 2017. "Backlash: The Politics and Real-World Consequences of Minority Group Dehumanization." Personality and Social Psychology Bulletin 43 (1): 87-104.

Kumasi, Kafi. 2012. "Roses in the Concrete.” Knowledge Quest 40 (5): 32-37. 
Lankes, R. David. 2016. "The Knowledge School and an Election Mandate." R. David Lankes (blog), November 9. https://davidlankes.org/?pp9047.

Lankes, R. David. 2017. "Celebration through Action: The Obligation of Information and Communications in a Time of Alternative Facts." R. David Lankes (blog), February 24. https://davidlankes.org/?pp9255.

Mangan, Dan. 2016. "Trump: I'll Appoint Supreme Court Justices to Overturn Roe v. Wade Abortion Case." CNBC, October 19. http://www.cnbc.com/2016/10/19/trump-ill-appointsupreme-court-justices-to-overturn-roe-v-wade-abortion-case.html.

Masri, Ahmad, and Mourad H. Senussi. 2017. "Trump's Executive Order on ImmigrationDetrimental Effects on Medical Training and Health Care." New England Journal of Medicine 376:e39. http://www.nejm.org/doi/full/10.1056/NEJMp1701251\#tparticle.

McCarthy, Michael. 2017. "Trump Signs Order Targeting Key Elements of Affordable Care Act." BMJ 356:406. doi:https://doi.org/10.1136/bmj.j406.

McDonald, Katrina Bell, and Adia Harvey Wingfield. 2008. "(In)visibility Blues: The Paradox of Institutional Racism." Sociological Spectrum 29 (1): 28-50.

McDonough, Patricia M. 1997. Choosing Colleges: How Social Class and Schools Structure Opportunity. Albany, NY: SUNY Press.

Meyers, Eric M., Karen E. Fisher, and Elizabeth Marcoux. 2007. "Studying the Everyday Information Behavior of Tweens: Notes from the Field." Library and Information Science Research 29 (3): 310-31.

Monroe, Carla R. 2005. "Why Are 'Bad Boys' Always Black? Causes of Disproportionality in School Discipline and Recommendations for Change." Clearing House 79 (1): 45-50.

Moore, Sharon E., Michael A. Robinson, Christson Adedoyin, Michael Brooks, Dana K. Harmon, and Daniel Boamah. 2016. "Hands Up-Don't Shoot: Police Shooting of Young Black Males: Implications for Social Work and Human Services." Journal of Human Behavior in the Social Environment 26 (3-4): 254-66.

Morris, Monique. 2016. Pushout: The Criminalization of Black Girls in Schools. New York: New.

Mowatt, Rasul A., Bryana H. French, and Dominique A. Malebranche. 2013. "Black/Female/Body Hypervisibility and Invisibility: A Black Feminist Augmentation of Feminist Leisure Research." Journal of Leisure Research 45 (5): 644-60.

Mueller, Kami. 2016. "NCGOP Sees Encouraging Early Voting, Obama/Clinton Coalition Tired, Fail to Resonate in North Carolina." Press release. Raleigh, NC: North Carolina Republican Party. http://us2.campaignarchive2.com/?upf3100bc5464cbba2f472ddf2c\&idpe4b9a8fb19.

Nagel, Caroline. 2016. "Southern Hospitality?: Islamophobia and the Politicization of Refugees in South Carolina during the 2016 Election Season." Southeastern Geographer 56 (3): 283-90.

Nelson, Louis. 2016. "Trump Calls for Nationwide 'Stop-and-Frisk' Policy." Politico, November 21. http://www.politico.com/story/2016/09/donald-trump-stop-and-frisk-228486. 
Osborne, Robin, ed. 2004. From Outreach to Equity: Innovative Models of Library Policy and Practice. Chicago: American Library Association.

Pawley, Christine. 2006. "Unequal Legacies: Race and Multiculturalism in the LIS Curriculum." Library Quarterly 76 (2): 149-68.

Pettit, Becky, and Brian L. Sykes. 2015. "Civil Rights Legislation and Legalized Exclusion: Mass Incarceration and the Masking of Inequality." Sociological Forum 30 (1): 589-611.

Rupar, Aaron. 2016. "Donald Trump Thanks African Americans for Not Voting." Think Progress, December 16. https://thinkprogress.org/donald-trump-thanks-african-americans-for-notvoting-2d35fbf00753\#.v7j1x2rgq.

Schroeder, Robert, and Christopher V. Hollister. 2014. "Librarians' Views on Critical Theories and Critical Practices." Behavioral and Social Sciences Librarian 33 (2): 91-119.

Smith, Edward J., and Shaun R. Harper. 2015. Disproportionate Impact of K-12 School Suspension and Expulsion on Black Students in Southern States. Philadelphia: Center for the Study of Race and Equity in Education, University of Pennsylvania. https://www.gse.upenn.edu/equity/sites/gse.upenn.edu.equity/files/publications/Smith_H arper_Report.pdf.

Solórzano, Daniel G., and Tara J. Yosso. 2001. "Critical Race and LatCrit Theory and Method: Counter-Storytelling." International Journal of Qualitative Studies in Education 14 (4): 471-95.

Southern Poverty Law Center. 2016. The Trump Effect: The Impact of the 2016 Presidential Election on Our Nation's Schools. Montgomery, AL: Southern Poverty Law Center. https://www.splcenter.org/sites/default/files/the_trump_effect.pdf.

Stringer, Jordan T. 2008. "Criminalizing Voter Suppression: The Necessity of Restoring Legitimacy in Federal Elections and Reversing Disillusionment in Minority Communities." Emory Law Journal 57 (4): 1011-48.

Sue, Derald W. 2004. "Whiteness and Ethnocentric Monoculturalism: Making the 'Invisible' Visible." American Psychologist 59 (8): 761-69.

Tewell, Eamon. 2016. "Putting Critical Information Literacy into Context: How and Why Librarians Adopt Critical Practices in Their Teaching." In the Library with the Lead Pipe, October 12. http://www.inthelibrarywiththeleadpipe.org/2016/putting-critical-informationliteracy-into-context-how-and-why-librarians-adopt-critical-practices-in-their-teaching/.

Villalpando, Octavio, and Dolores Delgado Bernal. 2002. "A Critical Race Theory Analysis of the Barriers That Impede the Success of Faculty of Color." In The Racial Crisis in American Higher Education, edited by William A. Smith, Philip Altbach, and Kofi Lomotey. Albany, NY: SUNY Press.

Widdersheim, Michael M., and Melissa A. McCleary. 2016. "Gender and Sexuality, Self-Identity, and Libraries: Readers' Advisory as a Technique for Creative (Dis)Assembly." Library Trends 64 (4): 714-40. 
Wun, Connie. 2016. "Unaccounted Foundations: Black Girls, Anti-Black Racism, and Punishment in Schools." Critical Sociology 42 (4-5): 737-50.

Yosso, Tara J. 2006. "Whose Culture Has Capital: A Critical Race Theory Discussion of Community Cultural Wealth." In Critical Race Theory in Education: All God's Children Got a Song, edited by A. D. Dixson and C. K. Rousseau. New York: Taylor \& Francis.

\section{Authors}

Amelia N. Gibson: assistant professor at the School of Information and Library Science at the University of North Carolina at Chapel Hill. Gibson's primary research interests center on health information behavior and on local communities and places as information systems. She is particularly interested in the effects of place, space, and community on the information worlds and information behavior, information needs, and information access of various populations. Her current work focuses on information poverty and how intersections of identity, place, space, and social and economic power and privilege influence information access and information behavior. Her most recent article is "Building a Progressive-Situational Model of Post-Diagnosis Information Seeking for Parents of Individuals with Down Syndrome" (2016) in Global Qualitative Nursing Research.

\section{http://www.ameliagibson.com}

Sandra Hughes-Hassell: professor in the School of Information and Library Science at the University of North Carolina at Chapel Hill. Hughes-Hassell is also president elect of the Young Adult Library Services Association. In her current research, she focuses on social justice issues in youth library services, diverse youth literature, and culturally responsive professional development. She has written and presented extensively on culturally relevant pedagogy, critical race theory, and the role of libraries in serving youth of color. Her most recent book is Libraries, Literacy, and African American Youth (Libraries Unlimited, 2017), which she co-edited with Pauletta B. Bracy and Casey H. Rawson.

E-mail:smhughes@email.unc.edu. 